\title{
SOFT TISSUE TUMOR
}

\section{Anindhita Pangestika, Lalu Wisnu R Danu N}

Fakultas Kedokteran, Universitas Mataram, Indonesia.

Email: anindhitap27@gmail.com , laludanuu@gmail.com

\begin{abstract}
Abstrak
Tumor jaringan lunak adalah kelompok heterogen dari lesi jinak dan ganas yang berkembang dari berbagai nonepitel, elemen ekstraskeletal, termasuk jaringan adiposa, otot polos dan rangka, tendon, tulang rawan, jaringan fibrosa, pembuluh darah, dan struktur limfatik. Penelitian ini bertujuan untuk mengetahui bagaimana soft tissue tumor bekerja dan bagaimana cara mengobatinya. Penulisan artikel ini mencakup berbagai sumber yang berasal dari jurnal ilmiah dan pedoman pemerintah maupun instansi terkait. Pencarian sumber dilakukan di portal online publikasi jurnal seperti MedScape, Google Scholar (scholar.google.com) dan National Center for Biotechnology Information (ncbi.nlm.nih.gov), dengan kata kunci "Soft Tissue Tumor". Tumor jaringan lunak (STT) dapat bersifat jinak atau ganas, dan tumor jaringan lunak jinak lebih sering terjadi dibandingkan tumor ganas dengan perbandingan 100:1. Dalam suatu penelitian terhadap 93 kasus tumor jaringan lunak, ditemukan bahwa kejadian tumor jinak tumor adalah $75,2 \%$ dan tumor ganas adalah $24,8 \%$. Tumor jaringan lunak berhubungan dengan kondisi genetik, radiasi, limfedema kronis, karsinogen lingkungan, dan infeksi.
\end{abstract}

Kata Kunci: Soft tissue tumors; Jinak, Ganas; Pasien

\begin{abstract}
Soft tissue tumors are a heterogeneous group of benign and malignant lesions that develop from a variety of nonepithelial, extraskeletal elements, including adipose tissue, smooth and skeletal muscle, tendons, cartilage, fibrous tissue, blood vessels, and lymphatic structures. The writing of this article includes various sources originating from scientific journals and government guidelines and related agencies. Source searches were carried out on online portals for journal publications such as Med Scape Google Scholar (scholar.google.com) and the National Centre for Biotechnology Information/NCBI (ncbi.nlm.nih.gov), with the keyword "Sensoric Nerve Trauma". Soft tissue tumors (STT) can be benign or malignant, and benign soft tissue tumors are more common than malignant tumors with a ratio of 100: 1. In a study of 93 cases of soft tissue tumors, it was found that the incidence of benign tumors was $75.2 \%$ and malignant tumors were $24.8 \%$. Soft tissue tumors are associated with
\end{abstract}


genetic conditions, radiation, chronic lymphedema, environmental carcinogens, and infections.

Keywords : Soft tissue tumors, benign, malignant, patients

Diterima: 15-11-2021

Direvisi: $10-12-2021$

Diterbitkan: 20-12-2021

\section{Pendahuluan}

Kanker merupakan penyebab kematian utama kedua yang memberikan kontribusi $13 \%$ kematian dari $22 \%$ kematian akibat penyakit tidak menular utama di dunia (Oemiati et al., 2011). Berdasarkan data WHO, diperkirakan terdapat 18.1 juta kasus baru dan 9.6 juta kematian akibat kanker pada tahun 2018. Meningkatnya jumlah penderita kanker dapat disebabkan oleh beberapa faktor, antara lain pertumbuhan penduduk dan penuaan serta perubahan prevalensi penyebab tertentu kanker yang terkait dengan pembangunan sosial dan ekonomi (World Health Organization, 2018). Masalah penyakit kanker di Indonesia hampir 70\% ditemukan dalam keadaan stadium yang sudah lanjut (Oemiati et al., 2011).

Jaringan lunak merujuk pada otot, lemak, jaringan fibrosa, pembuluh darah, maupun jaringan lain yang menyokong tubuh. Tumor jaringan lunak atau soft tissue tumor (STT) dapat bersifat jinak maupun ganas, dan tumor jaringan lunak jinak lebih umum ditemukan daripada tumor ganas dengan perbandingan 100:1 (Soni et al., 2014). Penyebab sebagian besar tumor jaringan lunak belum diketahui. Tumor jaringan lunak dapat timbul di lokasi manapun diantaranya adalah ekstremitas bawah terutama paha $(40 \%)$, ekstremitas atas $(20 \%)$ kepala dan leher (10\%), dan di tubuh serta peritoneum (30\%) (Kumar et al., 2015).

Tumor jaringan lunak ganas hanya mewakili $1 \%$ dari semua tumor ganas pada orang dewasa. Subkelompok tumor jaringan lunak terbesar pada orang dewasa adalah tumor adipositik dimana liposarcoma yang termasuk dalam subkelompok ini merupakan salah satu tumor jaringan lunak ganas yang paling umum pada orang dewasa. Pada pediatrik, tumor jaringan lunak ganas mewakili $15 \%$ dari seluruh tumor ganas dan rhabdomyosarcoma adalah tumor jaringan lunak ganas yang paling umum (Demetri et al., 2010; Fenzl et al., 2017).

Definisi

Tumor jaringan lunak adalah kelompok heterogen lesi jinak dan ganas yang berkembang dari berbagai elemen nonepitel, ekstraskeletal, termasuk jaringan adiposa, otot polos dan rangka, tendon, tulang rawan, jaringan fibrosa, pembuluh darah, dan struktur limfatik (Razek \& Huang, 2011). Soft Tissue Sarcomas (STS) merupakan salah satu jenis sarkoma, yaitu kelompok tumor heterogen yang berasal dari mesoderm embrio, dan merupakan tumor ganas yang jarang terjadi (Wirawan \& Gonhowiardjo, 2014). 


\section{Epidemiologi}

Secara keseluruhan, kejadian tahunan sarkoma jaringan lunak yang disesuaikan dengan usia berkisar antara 15 hingga 35 per 1 juta populasi. Insidensinya terus meningkat seiring bertambahnya usia dan sedikit lebih tinggi pada pria dibandingkan pada wanita. Tumor jaringan lunak ganas terjadi dua kali lebih sering dari sarkoma tulang primer. Sekitar $45 \%$ sarkoma terjadi di ekstremitas bawah, 15\% di ekstremitas atas, $10 \%$ di daerah kepala dan leher, $15 \%$ di retroperitoneum, dan $15 \%$ sisanya di dinding perut dan dada (Sidham, 2020). Paling umum terjadi adalah Malignant Fibrous Histiocytoma/MFH (28\%), leiomyosarkoma (12\%), liposarkoma (15\%), sarkoma sinovial (10\%), dan Malignant Peripheral Nerve Sheath Tumor/MPNST (6\%) (Wirawan \& Gonhowiardjo, 2014). Rhabdomio sarkoma adalah STS yang paling sering terjadi pada anak-anak (Wirawan \& Gonhowiardjo, 2014).

\section{Etiologi}

1. Kondisi Genetik

Banyak gen penekan tumor, onkogen, dan cacat sitogenetik sekarang dikaitkan dengan berbagai sarkoma jaringan lunak. Contohnya benign schwannoma dikarenakan sitogenetik monosomi 22, desmoid tumor karena trisomy 8.

2. Radiasi

Mekanisme patogenik adalah munculnya mutasi genetic akibat radiasi yang mendorong transformasi neoplastik.

3. Limfedema kronis

Seperti yang diamati pada pasien dengan karsinoma payudara stadium akhir, limfedema kronis dapat mempengaruhi individu untuk berkembangnya limfangiosarkoma.

4. Karsinoge Lingkungan

Hubungan antara paparan berbagai karsinogen dan peningkatan insiden tumor jaringan lunak telah dilaporkan. Terjadinya angiosarkoma hati, misalnya, telah dikaitkan dengan paparan arsenik, torium dioksida, dan vinil klorida.

5. Infeksi

Contoh klasik tumor jaringan lunak yang diinduksi infeksi adalah sarkoma Kaposi akibat virus herpes manusia tipe 8 pada pasien dengan human immunodeficiency virus (HIV). Infeksi virus Epstein-Barr pada inang yang mengalami gangguan sistem imun juga meningkatkan kemungkinan perkembangan tumor jaringan lunak (Sidham, 2020).

\section{Patogenesis atau Patofisiologi}

Mutasi gen adalah faktor predisposisi untuk beberapa tumor jaringan lunak dan gen memiliki peran penting perihal diagnosis. Dalam beberapa kasus, seperti individu berasal dari keluarga dengan kondisi predisposisi bawaan, seperti sindrom Li- 
Fraumeni (LFS) yang merupakan kelainan autosomal dominan yang terkait dengan mutasi hilangnya fungsi germline pada TP53 yang berperan dalam menekan perkembangan neoplasia atau tumor suppressor gene. Hal ini terjadi pada> 50\% dari semua jenis kanker. Berdasarkan data dari database International Agency for Research Cancer TP53, sarkoma mewakili $17,4 \%$ dari semua kanker pada pembawa mutasi germline TP53 dan 36,8\% dari semua kanker pada pasien yang berusia kurang dari 20 tahun (Farid et al., 2016; Mertens et al., 2015).

Selain itu pada soft tissue tumor terjadi fusi gen yang telah dijelaskan pada sekitar sepertiga dari tumor jaringan lunak (STT). Dari 142 fusi berbeda yang telah dilaporkan, lebih dari setengahnya berulang dalam subtipe histologis yang sama. Fusi gen ini merupakan mutasi pendorong yang penting, dan studi rinci tentang efek selulernya telah memberikan pengetahuan penting tentang mekanisme patogenetik pada STT. Fusi gen, yaitu penjajaran dua gen yang mengarah ke terjemahan protein yang dideregulasi dan / atau chimeric, telah dijelaskan di semua jenis utama neoplasia, termasuk tumor jinak maupun ganas yang berasal dari hematologi, epitel, dan mesenkim (Farid et al., 2016; Mertens et al., 2015).

\begin{tabular}{lll} 
Chromosomal translocations in malignant soft tissue tumors & \\
\hline Soft tissue sarcoma & Translocation & Gene fusion product \\
\hline Alveolar rhabdomyosarcoma & $\mathrm{t}(2 ; 13)(\mathrm{q} 35 ; \mathrm{q} 14)$ & PAX3-FKHR \\
Alveolar soft part sarcoma & $\mathrm{t}(\mathrm{X} ; 17)(\mathrm{p} 11 ; \mathrm{q} 25)$ & ASPL-TFE3 \\
Clear cell sarcoma & $\mathrm{t}(12 ; 22)(\mathrm{q} 13 ; \mathrm{q} 12)$ & EWS-ATF1 \\
Dermatofibrosarcoma protuberans/giant cell fibroblastoma & $\mathrm{t}(17 ; 22)(\mathrm{q} 21 ; \mathrm{q} 13)$ & COL1A1-PDGFB \\
Ewing sarcoma/PNET & $\mathrm{t}(11 ; 22)(\mathrm{q} 24 ; \mathrm{q} 12)$ & EWS-FLI1 \\
& $\mathrm{t}(21 ; 22)(\mathrm{q} 22 ; \mathrm{q} 12)$ & EWS-ERG \\
Infantile fibrosarcoma & $\mathrm{t}(12 ; 15)(\mathrm{p} 13 ; \mathrm{q} 26)$ & ETV6-NTRK3 \\
Myxoid round cell liposarcoma & $\mathrm{t}(12 ; 16)(\mathrm{q} 13 ; \mathrm{p} 11)$ & FUS-CHOP \\
Synovial sarcoma & $\mathrm{t}(\mathrm{X} ; 18)(\mathrm{p} 11.2 ; \mathrm{q} 11.2)$ & SYT-SSX1 \\
& & SYT-SSX2 \\
\hline
\end{tabular}

Sumber: (Katenkamp and Katenkamp, 2009)

Gambaran/Manifestasi Klinis

Berdasarkan jenis jaringan yang membentuknya, umumnya tumor jaringan lunak diklasifikasikan seperti jaringan lemak,jaringan fibrosa, otot, dan jaringan neurovascular. Semua jaringan nonepitel selain dari tulang, tulang rawan otak dan selaputnya, SSP, sel hematopoetik dan jaringan limfoid merupakan soft tissue atau jaringan lunak (Prajoko, 2018). 


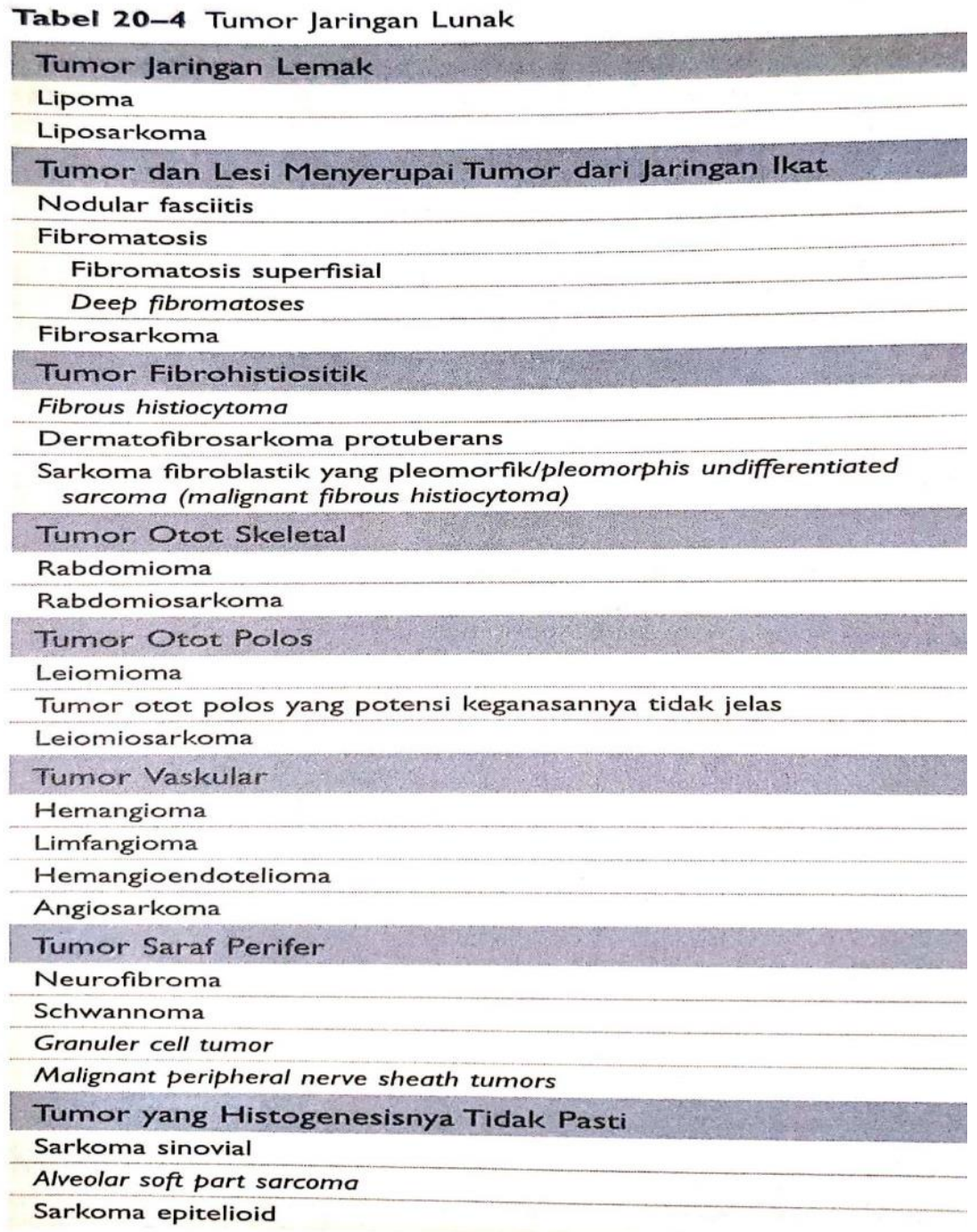

1. Lipoma

Gambaran klinisnya berupa benjolan dengan diameter 2-10 cm, kenyal dan lembut, lambat membesar, tidak terasa nyeri dan dapat bergerak bebas di kulit. Lipoma yang konvensional (subtipe paling sering) lunak, ukurannya bervariasi pada pemeriksaan histologis terdiri atas sel lemak putih yang matur tanpa pleomorfi.

2. Liposarkoma

Liposarcoma biasanya berupa lesi yang berbatas tegas. Kebanyakan liposarcoma berada di jaringan lunak bagian dalam prognosisnya sangat dipengaruhi oleh subtipe histologisnya, jenis miksoid/bulat dan pleomorfik yang agresif, pertumbuhan yang cepat, cenderung rekuren sesudah eksisi dan bermetastasis ke paru.

3. Fibroma

Jaringan ini tumbuh akibat adanya trauma yang berlangsung terus menerus. Gambaran atau manifestasi klinisnya terdapat massa yang berbentuk bulat, bertangkai, dan mencapai ukuran maksimal dalam waktu beberapa bulan 
dengan ukuran tidak lebih dari $3 \mathrm{~cm}$ dan tidak terasa nyeri. Pada pemeriksaan biopsy permukaan lesi ditutupi oleh selapis sel skuamosa bertingkat dan umumnya terlihat teratur.

4. Fibrosarkoma

Ciri khas dari fibrosarcoma adalah tumbuh dibagian dalam jaringan paha, lutut, dan retroperitoneal, biasanya sudah ada beberapa tahun pada saat di diagnosis dan tumbuh lambat.sebagaimana dengan sarcoma lainnya fibrosarcoma sering terjadi kekambuhan sesudah eksisi ( lebih dari 50\% kasus) dan dapat bermetastasis.

5. Leiomioma

Sering terjadi sebagai neoplasma yang berbatas tegas yang berasal dari otot polos diseluruh tubuh namun yang paling sering adalah dibagian uterus dan kulit. Pada pemeriksaan histopatologis didapatkan inti dengan karateristik halus yang memanjang dengan ujung tumpul.

6. Leiomiosarkoma

Kulit dan jaringan lunak bagian dalam, ekstremitas dan retroperitoneum (vena kava inferior) merupakan tempat yang paling sering. Neoplasma dengan massa yang keras, tanpa nyeri, tumor peritoneal dapat membesar dan menimbulkan keluhan pada abdomen. Pada pemeriksaan histopatologis apabila ditemukan intisel berjumlah 5-10 maka disebut high grade.

7. Rabdomioma

Rabdomioma adalah tumor otot lurik. Terdapat rabdomioma neoplastik dan hematoma. Pada pemeriksaan fisik pada pasien terdapat adanya massa polypoid di wilayah leher sedangkan pada rabdomioma jantung terdapat murmur jantung. Pada biopsy ditemukan adanya sel sel besar yang menyerupai otot lurik, inti berada di perifer.

8. Rabdomiosarkoma

Merupakan sarcoma jaringan lunak yang paling sering terjadi pada anak anak dan remaja. Tampilan makroskopik dari tumor ini bervariasi apabila timbul di dekat permukaan vagina atau kandung kemih dapat menunjukan massa yang lunak seperti agar agar, menyerupai anggur, dan menggambarkan sarkoma botryoides dan pada kasus lain terlihat massa yang putih kecoklatan infiltrative dan berbatas tidak jelas. 
Penatalaksanaan

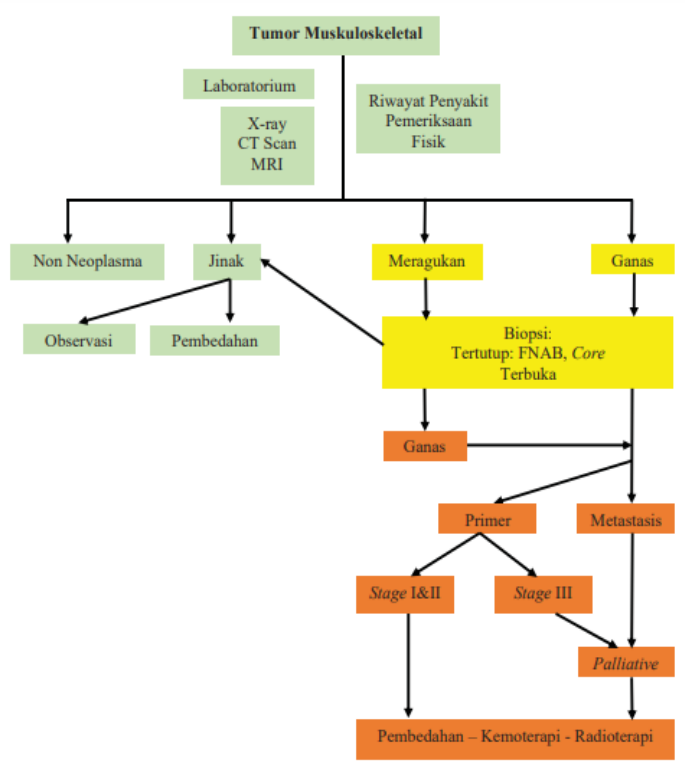

Gambar algoritma penatalaksanaan tumor musculoskeletal (Mahyudin, 2017)

Terapi pada tumor muskuloskeletal bervariasi, mulai dari observasi, kemoterapi, pembedahan, dan radioterapi. Terapi pada tumor jaringan lunak ditentukan oleh ukuran tumor, sifat biologis tumor, gangguan pada struktur di sekitarnya dan keluhan nyeri yang diderita pasien. Umumnya tumor jinak yang ukurannya kurang dari $3 \mathrm{~cm}$ dan tidak aktif cukup dilakukan observasi saja,. Pada tumor jinak yang aktif, tumbuh membesar, menimbulkan kerusakan tulang sehingga berpotensi menimbulkan fraktur patologis, menekan jaringan sekitarnya sehingga menimbulkan gangguan sesuai dengan jaringan yang terganggu serta menimbulkan nyeri yang mengganggu pada penderita, maka dianjurkan untuk diambil melalui proses pembedahan (Mahyudin, 2017).

Pembedahan sampai saat ini masih merupakan pilihan utama untuk tumor ganas sistem muskuloskeletal, tetapi harus diingat bahwa setiap tumor ganas dari manapun sumbernya memiliki kemampuan untuk metastasis ke organ lain. Kemampuan tumor ganas untuk metastasis tidak bisa diatasi dengan pembedahan, sehingga dibutuhkan terapi yang bersifat sistemik seperti kemoterapi sebagai terapi tambahan (adjuvant), walaupun begitu tidak semua tumor ganas muskuloskeletal sensitif terhadap kemoterapi. Radioterapi bisa menjadi pilihan lain untuk terapi tambahan dan juga sebagai terapi utama untuk tumor ganas muskuloskeletal yang tidak dapat dioperasi (non-operable) (Mahyudin, 2017).

Berikut pedoman penatalaksanaan tumor ganas pada jaringan lunak menurut NCCN Clinical Practice Guideline in Oncology (Mahyudin, 2017). 


\begin{tabular}{|c|c|c|c|c|}
\hline Stage & $\begin{array}{l}\text { Primary } \\
\text { Treatment }\end{array}$ & & & Follow-up \\
\hline $\begin{array}{l}\text { Stadi- } \\
\text { um IA } \\
\text { (Tla-Ib, } \\
\text { N0, M0), } \\
\text { derajat } \\
\text { rendah }\end{array}$ & & $\begin{array}{l}\text { Margin } \\
\text { onkologi } \\
\text { yang sesuai } \\
\text { atau fasia } \\
\text { intak }\end{array}$ & & $\begin{array}{l}\text { - Evaluasi rehabilitasi } \\
\text { (OT,PT), diterus- } \\
\text { kan hingga fungsi } \\
\text { maksimal dapat } \\
\text { tercapai } \\
\text { - H\&P setiap 3-6 }\end{array}$ \\
\hline $\begin{array}{l}\text { Stadi- } \\
\text { um Ib } \\
\text { (T2a-2b, } \\
\text { N0, M0), } \\
\text { derajat } \\
\text { rendah }\end{array}$ & $\begin{array}{l}\text { Operaif untuk } \\
\text { mendapatkan } \\
\text { margin onkolo- } \\
\text { gis yang cukup }\end{array}$ & $\begin{array}{l}\text { Gagal } \\
\text { dalam } \\
\text { mendapat- } \\
\text { kan margin } \\
\text { onkologi- } \\
\text { yang sesuai } \\
\text { (dan tanpa } \\
\text { fasia yang } \\
\text { intak }\end{array}$ & \begin{tabular}{l} 
- Re-reseksi \\
\multicolumn{1}{c}{ atau } \\
- Observasi (untuk \\
tumor stadium la) \\
- Atau \\
pertimbangkan \\
radioterapi
\end{tabular} & $\begin{array}{l}\text { pada umumnya 2-3 } \\
\text { tahun, dan selanjut- } \\
\text { nya tiap tahun } \\
\text { - Pertimbangkan un- } \\
\text { tuk foto thorax } \\
\text { - Pertimbangkan } \\
\text { untuk mendapat- } \\
\text { kan baseline pasca } \\
\text { operasi dan pe- } \\
\text { meriksaan radiol- } \\
\text { ogis pada tempat } \\
\text { lesi secara berkala } \\
\text { berdasarkan pada } \\
\text { risiko estimasi } \\
\text { rekurensi lokal dan } \\
\text { regional }\end{array}$ \\
\hline
\end{tabular}

\begin{tabular}{|c|c|c|c|c|c|}
\hline Presentasi & Stadium & \multicolumn{3}{|c|}{ Terapi primer } & Follow-up \\
\hline \multirow{7}{*}{$\begin{array}{l}\text { Stadium II,III } \\
\text { Yang dapat } \\
\text { direseksi } \\
\text { dengan } \\
\text { hasil memillki } \\
\text { fungsi yang } \\
\text { baik }\end{array}$} & \multirow{3}{*}{$\begin{array}{l}\text { Scadium IIA } \\
\text { (Tla-b, NO, } \\
\text { MO, G2-3) }\end{array}$} & $\begin{array}{l}\text { Operasi untuk } \\
\text { mendapat- } \\
\text { kan margin } \\
\text { onkologi yang } \\
\text { tepat } \\
\text { atau }\end{array}$ & & & \multirow{7}{*}{$\begin{array}{l}\text { - Evaluasi } \\
\text { rehabilitasi } \\
\text { (OT, PT), lan- } \\
\text { jutkan hingga } \\
\text { tercapai fungsi } \\
\text { maksimal } \\
\text { - H \& P tiap 3- } \\
6 \text { bulan selama } \\
2-3 \text { tahun, } \\
\text { selanjutmya } \\
\text { tiap } 6 \text { bulan } \\
\text { selama } 2 \text { tahun } \\
\text { berikutnya, dan } \\
\text { selanjutmya } \\
\text { tiap tahun } \\
\text { Pertimbangkan } \\
\text { untuk foto } \\
\text { thorax } \\
\text { Pertimbangkan } \\
\text { baseline pasca } \\
\text { operasi dan } \\
\text { pemeriksaan } \\
\text { radiologis pada } \\
\text { lokasi primer } \\
\text { secara berkala } \\
\text { berdasarkan } \\
\text { estimasi risiko } \\
\text { rekurensi lokal } \\
\text { regional }\end{array}$} \\
\hline & & $\begin{array}{l}\text { Operasi untuk } \\
\text { mendapat- } \\
\text { kan margin } \\
\text { onkologi yang } \\
\text { tepat } \\
\text { atau }\end{array}$ & Radioterapi & & \\
\hline & & $\begin{array}{l}\text { Radioterapi } \\
\text { preoperatif }\end{array}$ & $\begin{array}{l}\text { Operasi un- } \\
\text { tuk mendapa- } \\
\text { tkan margin } \\
\text { onkologi yang } \\
\text { tepat } \\
\text { atau }\end{array}$ & & \\
\hline & $\begin{array}{l}\text { Stadium } \\
\text { IIB,III (T2a-b, } \\
\text { N0,M0, G2) } \\
\text { Stadium III }\end{array}$ & $\begin{array}{l}\text { Operasi untuk } \\
\text { mendapat- } \\
\text { kan margin } \\
\text { onkologi yang } \\
\text { tepat } \\
\text { atau }\end{array}$ & & $\begin{array}{l}\text { Radioterapi } \\
\text { atau } \\
\pm \text { kemoterapi } \\
\text { adjuvan }\end{array}$ & \\
\hline & $\begin{array}{l}\text { (T2a-b, N0, } \\
\text { M0, G3 atau }\end{array}$ & $\begin{array}{l}\text { Radioterapi } \\
\text { preoperatif }\end{array}$ & $\begin{array}{l}\text { Operasi un- } \\
\text { tuk mendapa- }\end{array}$ & $\begin{array}{l}\text { Pertimbangkan } \\
\text { radioterapi tam- }\end{array}$ & \\
\hline & $\begin{array}{l}\text { NI, MO, G } \\
\text { berapapun }\end{array}$ & $\begin{array}{l}\text { Kemoradiasi } \\
\text { atau }\end{array}$ & $\begin{array}{l}\text { tkan margin } \\
\text { onkologi yang }\end{array}$ & $\begin{array}{l}\text { bahan } \\
\pm \text { kemoterapi }\end{array}$ & \\
\hline & & $\begin{array}{l}\text { Kemoterapi } \\
\text { preoperatif }\end{array}$ & atau & adjuvan & \\
\hline
\end{tabular}




\begin{tabular}{|c|c|c|c|c|c|}
\hline Stadium & $\begin{array}{l}\text { Terapi } \\
\text { primer }\end{array}$ & & & & Follow-up \\
\hline \multirow{3}{*}{$\begin{array}{l}\text { Stadium } \\
\text { II,III Dapat } \\
\text { dilakukan } \\
\text { reseksi } \\
\text { dengan } \\
\text { hasil yang } \\
\text { kurang } \\
\text { baik atau } \\
\text { penyakit } \\
\text { primer } \\
\text { yang tidak } \\
\text { dapat dir- } \\
\text { eseksi }\end{array}$} & \multirow{3}{*}{$\begin{array}{l}\text { Radioterapi } \\
\quad \text { Atau } \\
\text { Kemoradiasi } \\
\quad \text { Atau } \\
\text { Kemoterapi } \\
\quad \text { Atau } \\
\text { terapi re- } \\
\text { gional }\end{array}$} & \multirow[t]{2}{*}{$\begin{array}{l}\text { Dapat } \\
\text { direseksi } \\
\text { dengan } \\
\text { hasil yang } \\
\text { baik }\end{array}$} & \multirow[t]{2}{*}{$\begin{array}{l}\text { Operasi untuk } \\
\text { mendapatkan } \\
\text { margin onkologi } \\
\text { yang tepat }\end{array}$} & $\begin{array}{l}\text { Apabila } \\
\text { sebelum- } \\
\text { mya tidak } \\
\text { mendapat } \\
\text { radioterapi, } \\
\text { Radioterapi } \\
\text { Atau } \\
\text { Radioterapi } \\
\text { - kemoterapi } \\
\text { adjuvan }\end{array}$ & \multirow{3}{*}{$\begin{array}{l}\text { Evaluasi reha- } \\
\text { bilitasi (OT,PT), } \\
\text { lanjutkan hingga } \\
\text { tercapai fungsi } \\
\text { maksimal } \\
\text { H \& P tiap } 3 \text { - } 6 \\
\text { bulan selama } \\
2 \text { - } 3 \text { tahun, } \\
\text { selanjutnya tiap } \\
6 \text { bulan selama } \\
2 \text { tahun } \\
\text { berikutnya, dan } \\
\text { selanjutnya tiap } \\
\text { tahun } \\
\text { Pertimbangkan } \\
\text { untuk foto } \\
\text { thorax } \\
\text { Pertimbangkan } \\
\text { baseline pasca } \\
\text { operasi dan } \\
\text { pemeriksaan } \\
\text { radiologis pada } \\
\text { lokasi primer } \\
\text { secara berkala } \\
\text { berdasarkan } \\
\text { estimasi risiko } \\
\text { rekurensi lokal } \\
\text { regional }\end{array}$} \\
\hline & & & & $\begin{array}{l}\text { Pertimbang- } \\
\text { kan untuk } \\
\text { radioterapi } \\
\text { tambahan } \\
\pm \text { kemotera- } \\
\text { pi adjuvan }\end{array}$ & \\
\hline & & $\begin{array}{l}\text { Dapat } \\
\text { direseksi } \\
\text { dengan } \\
\text { hasil yang } \\
\text { kurang baik } \\
\text { Atau pen- } \\
\text { yakit prim- } \\
\text { er yang } \\
\text { tidak dapat } \\
\text { direseksi }\end{array}$ & $\begin{array}{l}\text { Opsi : } \\
\text { Jika sebelumnya } \\
\text { belum pernah } \\
\text { radioterapi, } \\
\text { maka dilakukan } \\
\text { radioterapi } \\
\text { Kemoterapi } \\
\text { Operasi paliatif } \\
\text { Observasi, apabila } \\
\text { asimptomatik } \\
\text { Terapi suportif } \\
\text { Amputasi }\end{array}$ & & \\
\hline
\end{tabular}

\begin{tabular}{|c|c|c|c|}
\hline Stadium & & Terapi primer & Follow-up \\
\hline \multirow[t]{2}{*}{$\begin{array}{l}\text { Sinkronis } \\
\text { stadium IV } \\
\text { (T berapap- } \\
\text { un, NI,T } \\
\text { berapapun, } \\
\text { M0, MI, G } \\
\text { berapapun }\end{array}$} & $\begin{array}{l}\text { Organ tung- } \\
\text { gal dan tumor } \\
\text { terbatas yang } \\
\text { dapat dilaku- } \\
\text { kan terapi } \\
\text { secara lokal }\end{array}$ & $\begin{array}{l}\text { Tatalaksana tumor primer } \\
\text { dan pertimbangan pilihan } \\
\text { - pilihan : } \\
\text { - metastasisktomi } \pm \\
\text { kemoterapi preoperatif } \\
\text { atau postoperatif } \pm \text { Ra- } \\
\text { dioterapi } \\
\text { - Ablasi (contoh: RFA } \\
\text { atau cryoterapi } \\
\text { - Embolisasi } \\
\text { - SBRT (stereotoctic body } \\
\text { radiation therapy) }\end{array}$ & $\begin{array}{l}\text { Evaluasi rehabilitasi (OT, PT), } \\
\text { lanjutkan hingga tercapai } \\
\text { fungsi maksimal } \\
\text { - } \mathrm{H} \& \mathrm{P} \text { tiap } 3-6 \text { bulan sela- } \\
\text { ma } 2-3 \text { tahun, selanjutnya } \\
\text { tiap } 6 \text { bulan selama } 2 \text { tahun } \\
\text { berikutnya, dan selanjutnya } \\
\text { tiap tahun } \\
\text { - Pertimbangkan untuk foto } \\
\text { thorax } \\
\text { - Pertimbangkan baseline pas- } \\
\text { ca operasi dan pemeriksaan } \\
\text { radiologis pada lokasi primer } \\
\text { secara berkala berdasarkan } \\
\text { estimasi risiko rekurensi lo- } \\
\text { kal regional }\end{array}$ \\
\hline & $\begin{array}{l}\text { Penyakit yang } \\
\text { menyebar }\end{array}$ & $\begin{array}{ll}\text { Pilihan paliatif } \\
\text { : } & \text { Kemoterapi } \\
\text { - } & \text { RT/SBRT } \\
\text { - } & \text { Pembedahan } \\
\text { - } & \text { Observaasi, apabila asimp } \\
\text { - } & \text { Terapi suportif } \\
\text { - } & \text { Ablasi (contoh: RFA atau } \\
\text { - } & \text { Embolisasi }\end{array}$ & $\begin{array}{l}\text { tomatik } \\
\text { cryoterapi) }\end{array}$ \\
\hline
\end{tabular}




\begin{tabular}{|c|c|c|}
\hline Kekambuhan & & Terapi \\
\hline Kekambuhan lokal & & Follow-up, dan selanjutnya alur terapi primer \\
\hline \multirow{3}{*}{$\begin{array}{l}\text { Penyakit } \\
\text { metastatik }\end{array}$} & $\begin{array}{l}\text { Organ tunggal dan tu- } \\
\text { mor terbatas yang dapat } \\
\text { dilakukan terapi secara } \\
\text { lokal }\end{array}$ & $\begin{array}{l}\text { Pilihan: } \\
\text { - metastasisktomi } \pm \text { kemoterapi preoperat- } \\
\text { if atau postoperatif } \pm \text { Radioterapi } \\
\text { - } \quad \text { Ablasi (contoh: RFA atau cryoterapi } \\
\text { - Embolisasi } \\
\text { - }\end{array}$ \\
\hline & Penyakit yang menyebar & 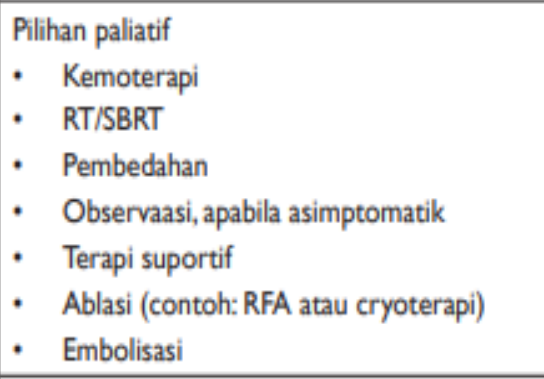 \\
\hline & $\begin{array}{l}\text { Penyakit yang terbatas } \\
\text { regional }\end{array}$ & $\begin{array}{l}\text { Pilihan: } \\
\text { - Diseksi limfonodi regional apabila ter- } \\
\text { dapat keterlibatan limfonodi } \pm \text { kemoterapi } \\
\pm \text { Radioterapi } \\
\text { - Metastasisktomi } \pm \text { kemoterapi preoperat- } \\
\text { if atau postoperatif } \pm \text { Radioterapi } \\
\text { - SBRT } \\
\text { - Perfusi Limd }\end{array}$ \\
\hline
\end{tabular}

\section{Hasil dan Pembahasan}

Tumor jaringan lunak diklasifikasikan berdasarkan klasifikasi WHO. Pada penelitian Gogoi tahun 2017, data yang relevan dikumpulkan dan dicatat seperti Umur, Jenis Kelamin, Lokasi tumor dan diagnosis akhir diberikan dengan karakteristik kasar dan mikroskopis. Sebanyak 5895 kasus dikumpulkan, di mana total 794 kasus tercatat sebagai tumor jaringan lunak. Pada Tabel 1, Di antara 794 sampel positif, 61 kasus ditemukan ganas dan kasus istirahat bersifat jinak. Berdasarkan Tabel 2, jenis histologis, jenis yang paling banyak ditemukan berasal dari jaringan otot yaitu 442 kasus (55,7\%), diikuti oleh jaringan pembuluh darah yaitu 157 kasus (19,8\%) dan jaringan lipomatosa yaitu 83 kasus (10,4\%). Jenis selubung saraf perifer dan fibroblastik saya ditemukan hampir sama. tumor telah disebutkan. Tumor jaringan lunak umumnya terlihat pada jenis kelamin perempuan $(79,0 \%)$. Lipoma dan hemangioma paling sering terlihat pada kedua jenis kelamin. Pada Tabel 3, beberapa jenis jaringan lunak jinak dan ganas yang umum pada wanita Tumor jinak yang paling umum adalah leiomioma diikuti oleh hemangioma, lipoma, fibroma, nevus, schwanomma dan neurofibroma sedangkan tumor ganas yang umum adalah Rhabdomyosarcoma diikuti oleh sarkoma sinovial (Gogoi, 2017). 


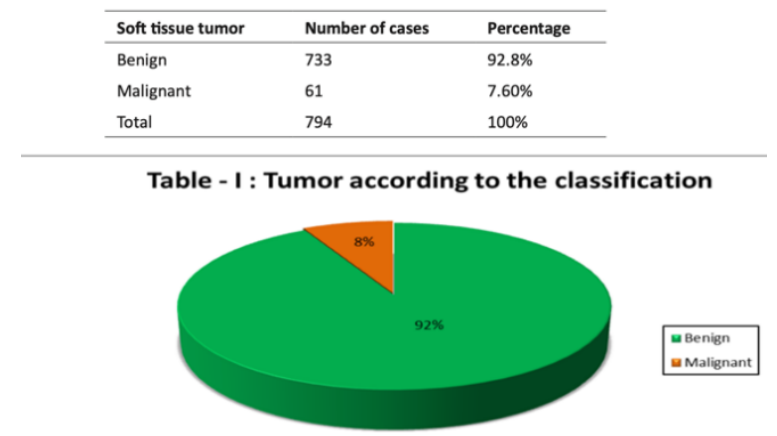

\begin{tabular}{lll}
\hline Histological type & Number of cases & Percentage \\
\hline Lipomatous tissues & 83 & $10.40 \%$ \\
Fibroblastic/Myofibroblastic tissues & 55 & $6.90 \%$ \\
Muscular tissues & 442 & $55.70 \%$ \\
Peripheral nerve sheath & 53 & $6.7 \%$ \\
Vascular tissues & 157 & $19.80 \%$ \\
Miscellaneous & 4 & $0.50 \%$ \\
Total & 794 & 100 \\
\hline
\end{tabular}

Table II: Tumor according to Histological Type
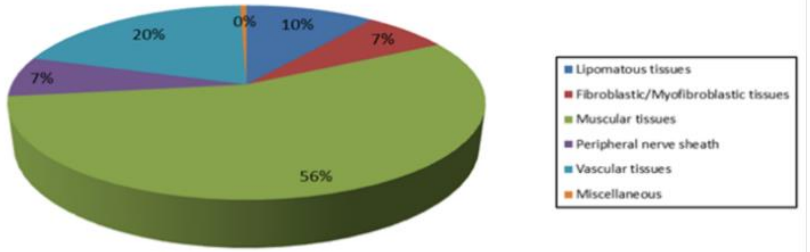

Pada penelitian yang dilakukan oleh Hassawi et al. didapatkan bahwa dari 93 tumor jaringan lunak, $70(75,2 \%)$ jinak dengan usia rata-rata 27 tahun dan 23 kasus $(24,8 \%)$ ganas dengan usia rata-rata 39 tahun. Tindakam Immunohistochemistery dilakukan pada 27 kasus didapatkan $21(77,7 \%)$ kasus tumor ganas dan $6(22,3 \%)$ kasus jinak. Tumor jinak yang paling umum adalah Lipoma, Haemangioma, Neurofibroma, sedangkan tumor otot ganas (leiomyosarcoma dan Rhabdomyosarcoma) dan tumor sel bulat ganas (Ewing's sarcoma / PNET) adalah kelompok utama (Hassawi et al., 2010).

Penelitian yang dilakukan oleh Hoven-Gondrie et al. secara keseluruhan, 3.066 pasien dilibatkan dalam penelitian ini. Histotipe berbeda antara pasien muda $(<65$ tahun) dan pasien lanjut usia ( $>65$ tahun) ( $p<0,001$ ). Pasien yang berusia di atas 65 tahun lebih sering didiagnosis dengan extremity sof tissue sarcoma (ESTS) stadium tinggi dan peningkatan proporsi ESTS tingkat tinggi $(\mathrm{p}<0,001)$. Proporsi pasien yang tidak menerima pengobatan meningkat seiring bertambahnya usia, dan lansia menerima lebih sedikit pengobatan modalitas gabungan. Usia secara signifikan dikaitkan dengan kelangsungan hidup relatif 5 tahun [72,7\% untuk pasien yang lebih muda dan 43,8\% untuk lansia tertua (>85 tahun)]. Dalam analisis multivariabel, usia masih menjadi faktor prognostik yang signifikan (Hoven-Gondrie et al., 2016).

\section{Kesimpulan}

Tumor jaringan lunak adalah kelompok heterogen lesi jinak dan ganas yang berkembang dari berbagai elemen nonepitel, ekstraskeletal Tumor jaringan lunak atau soft tissue tumor (STT) dapat bersifat jinak maupun ganas, dan tumor jaringan lunak 
jinak lebih umum ditemukan daripada tumor ganas dengan perbandingan 100:1. Insidensinya terus meningkat seiring bertambahnya usia dan sedikit lebih tinggi pada pria dibandingkan pada wanita. Penyebab dari tumor jaringan lunak diantaranya adalah kondisi genetik, radiasi, limfedema kronis, karsinogen lingkungan dan infeksi. 


\section{BIBLIOGRAFI}

Abbas, A.K., Aster, J.C., dan Kumar, V. (2015). Buku Ajar Patologi Robbins. Edisi 9. Singapura: Elsevier Saunders. Google Scholar

Demetri, G. D., Antonia, S., Benjamin, R. S., Bui, M. M., Casper, E. S. and Conrad, E. U. (2010) 'Soft tissue sarcoma', JNCCN Journal of the National Comprehensive Cancer Network, 8(6), pp. 630-674. doi: 10.6004/jnccn.2010.0049. Google Scholar

Farid, M. and Ngeow, J. (2016). Sarcomas Associated With Genetic Cancer Predisposition Syndromes: A Review. The Oncologist, 21(8), pp.1002-1013. Google Scholar

Fenzl, L., Mehrmann, M., Kremp, K. and Schneider, G. (2017) 'Weichteiltumoren: Epidemiologie, Klassifikation und Stadieneinteilung', Radiologe. Springer Verlag, 57(11), pp. 973-986. doi: 10.1007/s00117-017-0320-1. Google Scholar

Hassawi, BA., Suliman, AY., Hasan, IS. (2010). Soft tissue tumors - Histopathological study of 93 cases. Annals of the College of Medicine. Vol. 36 No. 1 \& 22010. Google Scholar

Hoven-Gondrie, M., Bastiaannet, E., Ho, V., van Leeuwen, B., Liefers, G., Hoekstra, H. and Suurmeijer, A., 2016. Worse Survival in Elderly Patients with Extremity SoftTissue Sarcoma. Annals of Surgical Oncology, 23(8), pp.2577-2585. Google Scholar

Mahyudin, F (Ed).( 2017), Diagnosis dan Terapi Tumor Muskuloskeletal (Multidiciplinary Approach). Jakarta: CV. Sagung Seto. Google Scholar

Mertens, F., Antonescu, C. and Mitelman, F. (2015). Gene fusions in soft tissue tumors: Recurrent and overlapping pathogenetic themes. Genes, Chromosomes and Cancer, 55(4), pp.291-310. Google Scholar

Oemiati, R., Rahajeng, E. and Yudi Kristanto, A. (2011) 'Prevalensi Tumor Dan Beberapa Faktor Yang Mempengaruhinya Di Indonesia, Buletin Penelitian Kesehatan, 39(4), pp. 190-204. Google Scholar

Prajoko, Y. W. (2018) 'Artikel A closer look at advanced breast cancer \& soft tissue sarcoma. Universitas diponegoro. Google Scholar

Razek, A.A., Huang, B.Y. (2011). Soft Tissue Tumors of the Head and Neck : Imagingbased Review of the WHO Classification 1. 35512. Google Scholar

Sidham, Vinod. B. (2020) Benign and Malignant Soft-Tissue Tumors. Retrieved from https://emedicine.medscape.com/article/1253816-overview.

Soni, P. B., Verma, A. K., Chandoke, R. K. and Nigam, J. S. (2014) 'A Prospective Study of Soft Tissue Tumors Histocytopathology Correlation', Pathology Research International, 2014. doi: 10.1155/2014/678628. Google Scholar

Wirawan S., Gondhowiardjo SA. (2014). Peranan radioterapi Terhadap Soft Tissue Sarcoma (STS) di Ekstremitas Sigit Wirawan, Soehartati A . Gondhowiardjo 
Abstrak / Abstract Informasi Artikel. 5(1), 34-41. Google Scholar

World Health Organization (2018) 'Latest Global Cancer Data: Cancer Burden Rises to 18.1 Million New Cases and 9.6 Million Cancer Deaths in 2018', International Agency for Research on Cancer. Google Scholar

First publication right:

Jurnal Syntax Fusion: Jurnal Nasional Indonesia

This article is licensed under:

(c) () (P) 